\title{
PENGARUH ACCOUNTING DISCLOSURE, ACCOUNTING HARMONIZATION DAN KOMITE AUDIT TERHADAP KUALITAS LABA (Studi pada Perusahaan Manufaktur yang terdaftar di BEI)
}

\author{
Tulus Suryanto \\ Fakultas Ekonomi dan Bisnis Islam, IAIN Raden Intan Lampung \\ Email: tulus@iainradenintan.ac.id
}

\begin{abstract}
This research aims to examine the effect of accounting disclosure, accounting harmonization and audit committies to earning quality. This research was conducted to manufacturing company listed on the stock excange from 2009 until 2013. Based on sample collecting using purposive sampling to obtain a sample of 48 companies. Data analysis uses SPSS programs with multiple regression analysis. The result showed that accounting disclosure hasn't effect to earning quality.In other hand, accounting harmonization and audit committies have a positif effect to earning quality.
\end{abstract}

Keywords: accounting disclosure, accounting harmonization, audit committies, earning quality

Abstrak: Penelitian ini bertujuan untuk menguji pengaruh pengungkapan akuntansi, akuntansi harmonisasi dan pemeriksaan committies untuk mendapatkan kualitas. Penelitian ini dilakukan untuk perusahaan manufaktur yang terdaftar di excange saham dari 2009 sampai 2013. Berdasarkan sampel mengumpulkan menggunakan purposive sampling untuk mendapatkan sampel dari 48 perusahaan. Analisis data menggunakan program SPSS dengan analisis regresi berganda. Hasil penelitian menunjukkan bahwa pengungkapan akuntansi belum berpengaruh ke pendapatan quality.In sisi lain, akuntansi harmonisasi dan pemeriksaan committies memiliki efek positif untuk mendapatkan kualitas.

Kata kunci: pengungkapan akuntansi, akuntansi harmonisasi, committies audit, kualitas produktif

\section{PENDAHULUAN}

Informasi laba merupakan salah satu bagian dari laporan keuangan yang banyak mendapat perhatian. Kebutuhan akan pembandingan laba antar perusahaan dan untuk memahami perbedaaan kualitas yang digunakan sebagai penilaian yang didasarkan pada laba, maka perlu dilakukan pengukuran atas kualitas. Kualitas laba tidak mempunyai ukuran yang mutlak, namun terdapat pendekatan kualitatif dan kuantitatif yang dapat digunakan untuk menganalisis dan menjelaskan kualitas laba. Pendekatan kuantitatif dengan menggunakan analisis rasio sedangkan pendekatan kualitatif berdasarkan pendapat (judgement) atau pandangan yang berlandaskan logika, pengalaman, dan wawasan. Kualitas laba juga merupakan jumlah yang dapat dikonsumsi dalam satu periode dengan menjaga kemampuan perusahaan pada awal dan akhir periode yang sama. Riset terkait kualitas laba telah banyak di lakukan. Suryana (2005) menemukan bahwa pasar menilai 
laba yang dilaporkan oleh perusahaan yang memiliki komite audit memiliki kualitas yang lebih baik daripada laba yang dilaporkan oleh perusahaan yang tidak memiliki komite audit. Riset lainnya yang cenderung mendukung keberadaan komite audit karena meningkatkan kualitas pelaporan keuangan antara lain, Jerry W. Lin, June F dan Li, Joon S. Yang, (2006), Klien (2001), DeFond dan Jiambalvo (1991), Beasly dan Salterio (2001).

Penelitian serupa dilakukan oleh Mayangsari (2009) yang menemukan bahwa peningkatan kualitas labapada laporan keuangan terjadi ketika standar akuntansi berkualitas tinggi. Pengungkapan akuntansi atau accounting disclosure merupakan standar dan praktik pengungkapan dipengaruhi oleh sumber-sumber keuangan, sistem hukum, ikatan politik, tingkat pembangunan ekonomi, tingkat pendidikan, budaya danpengaruh lainnya (Wijayanti, 2013). Penelitian Mayangsari (2009) menyatakan bahwa dari kualitas laba yang lebih tinggi, maka pendapatan akan terus meningkat sehingga mengakibatkan kualitas laba yang dilaporkan perusahaan juga tinggi.

Harmonisasi standar akuntansi merupakan isu yang hangat sejak era globalisasi dimulai. Harmonisasi tersebut diwujudkan dengan diterbitkannya International Financial Reporting Standards (IFRS) pada Juni 2003. Penerapan IFRS ini diharapkan dapat memberi banyak manfaat salah satunya adalah meningkatkan kualitas pelaporan keuangan bagi para pemegang kepentingan. Riset terkait pengaruh penerapan IFRS kebanyakan memperoleh hasil bahwa IFRS berpengaruh terhadap kualitas laba. Walaupun beberapa bertentangan. Ismail et al. (2010), Chiha et al. (2013), dan Osma dan Pope (2011) meneliti pengaruh penerapan IFRS pada kualitas laba yang masing-masing pada Malaysia, Prancis, dan di 28 negara melaporkan bahwa penerapan IFRS berpengaruh signifikan terhadap kualitas laba. Wardhani (2009) yang meneliti pengaruh tingkat konvergensi IFRS pada 10 negara di Asia melaporkan bahwa IFRS berpengaruh terhadap kualitas laba. Chen et al. (2010) yang meneliti pengaruh adopsi IFRS terhadap kualitas akuntansi di Uni Eropa melaporkan bahwa adopsi IFRS berpengaruh terhadap kualitas laba. Penelitian kali ini mencoba menggali pengaruh secara simultan antara Accounting Disclosure, Accounting Harmonization dan Komite Audit terhadap Kualitas Laba. Apakah dengan uji dan teknik analisa yang berbeda akan menghasilkan simpulan yang berbeda atau sebaliknya, sehingga akan menambah literature penelitian dan menjadi masukan bagi pihak yang berkepentingan.

\section{KAJIAN TEORI}

Accounting Disclosure. Di Indonesia peraturan yang mengatur tentang pengungkapan adalah keputusan Bapepam No. Kep-38/PM/1996. Informasi yang diungkapkan dalam laporan tahunan perusahaan dapat dikelompokkan menjadi dua, yaitu pengungkapan wajib (mandatory disclosures) dan pengungkapan sukarela (voluntary disclosures).

Pengertian Pengungkapan Sukarela menurut Meek dkk. (1995) adalah sebagai berikut: Pengungkapan sukarela merupakan pilihan bebas manajeman perusahaan untuk memberikan informasi akuntansi dan informasi lain yang relevan untuk pembuatan keputusan para pemakai laporan tahunan. Karena perusahaan memiliki keleluasan dalam melakukan pengungkapan sukarela dalam laporan tahunan sehingga menimbulkan adanya keragaman atau variasi luas pengungkapan sukarela antar perusahaan.

Tujuan yang positif dari Disclosure adalah untuk memberikan informasi yang penting dan relevan kepada para pemakai laporan keuangan, sehingga dapat membantu 
mereka dalam membuat keputusan dengan cara yang terbaik. Sejalan dengan tujuan dasar akuntansi, salah satu tujuan yang dicapainya adalah penyajian informasi yang cukup sehingga perbandingan dari hasil yang diharapkan dapat dilakukan. Evans (2003) dalam Suwardjono (2008) mengartikan pengungkapan sebagai berikut:

Disclosure means supplying information in the financial statements themselves, the notes to the statements, and the supplementary disclosure associated with the statements. It does not extend to public or private statements by made management or information provided outside the financial statement. Di sisi lain, pengungkapan sering juga memaknai sebagai penyediaan informasi lebih dari apa yang dapat disampaikan dalam bentuk statemen keuangan formal.

Accounting Harmonization. Harmonisasi standar akuntansi merupakan isu yang hangat sejak era globalisasi dimulai. Harmonisasi tersebut diwujudkan dengan diterbitkannya International Financial Reporting Standards (IFRS) pada Juni 2003. Penerapan IFRS ini diharapkan dapat memberi banyak manfaat salah satunya adalah meningkatkan kualitas pelaporan keuangan bagi para pemegang kepentingan. Namun manfaat ini juga dipengaruhi oleh lingkungan dimana IFRS tersebut diterapkan, dalam hal ini perlindungan yang diberikan bagi investor di suatu negara. Banyak penelitian telah dilakukan untuk meneliti manfaat penerapan IFRS

Komite Audit. Komite audit bertugas membantu dewan komisaris untuk memonitor proses pelaporan keuangan oleh manajemen untuk meningkatkan kredibilitas laporan keuangan (Bradbury et al. 2004). Tugas komite audit meliputi menelaah kebijakan akuntansi yang diterapkan oleh perusahaan, menilai pengendalian internal, menelaah sistem pelaporan eksternal dan kepatuhan terhadap peraturan. Di dalam pelaksanaan tugasnya komite menyediakan komunikasi formal antara dewan, manajemen, auditor eksternal, dan auditor internal (Bradbury et al., 2004).

Komite audit bertugas membantu dewan komisaris untuk memonitor proses pelaporan keuangan oleh manajemen untuk meningkatkan kredibilitas laporan keuangan (Bradbury et al. 2004). Tugas komite audit meliputi menelaah kebijakan akuntansi yang diterapkan oleh perusahaan, menilai pengendalian internal, menelaah sistem pelaporan eksternal dan kepatuhan terhadap peraturan. Di dalam pelaksanaan tugasnya komite menyediakan komunikasi formal antara dewan, manajemen, auditor eksternal, dan auditor internal (Bradbury et al., 2004).

Kualitas laba. Pengertian kualitas laba menurut Konsep Kualitatif Kerangka Kerja (International Accounting Standards Board, IASB, 2009). Laba yang berkualitas adalah laba yang bermanfaat dalam pengambilan keputusan yaitu memiliki karakteristik relevan, dapat dipahami, dapat dipercaya dan dapat diperbandingkan. Cho dan Jung dalam Boediono (2005), laba yangdipublikasikan dapat memberikan respon yang bervariasi sehingga menunjukkan adanya reaksi pasar terhadap informasi laba. Reaksi yang diberikan tergantung dari kualitas laba yang dihasilkan oleh perusahaan.

Pengembangan Hipotesis. Accounting disclosure atau pengungkapan akuntansi memiliki tujuan yang positif untuk memberikan informasi yang penting dan relevan kepada para pemakai laporan keuangan,. Dengan adanya pengungkapan akuntansi tersebut investor dapat dengan mudah mengetahui aspek-aspek terkait dengan nilai perusahaan serta aktivitas perusahaan. Investor juga mampu memperkirakan nilai dari jumlah, waktu dan 
ketidakpastian laba masa yang akan datang (kas masuk). Informasi akuntansi tersebut menjadi indikator bagi para investor didalam memprediksi prospek perusahaan dan juga memonitor kinerja perusahaan apakah telah berjalan sebagaimana mestinya atau tidak.

Sejumlah penelitian sebelumnya seperti Verrecchia, Eg Lang dan Lundholm (1993) dalam Banghoj dan Plenborg (2007) mencatat bahwa praktik pengungkapan yang lebih baik mampu meningkatkan pemahaman pengguna laporan tahunan (stakeholder) didalam usahanya untuk memahami nilai dari suatu perusahaan dengan cara meramalkan secara tepat nilai perusahaan dimasa datang dari perusahaan tersebut yang tergambarkan oleh nilai laba perusahaan tersebut

Harmonisasi akuntansi mulai diwujudkan dengan diterbitkannya diterbitkannya International Financial Reporting Standards (IFRS) pada Juni 2003. Chen et al. (2010) yang meneliti pengaruh adopsi IFRS terhadap kualitas akuntansi di Uni Eropa melaporkan bahwa adopsi IFRS berpengaruh terhadap kualitas laba. Sellami dan Fakhfakh (2013) meneliti pengaruh adopsi IFRS terhadap manajemen laba akrual dan riil di Prancis melaporkan bahwa IFRS menurunkan manajemen laba akrual maupun riil, sehingga menaikkan kualitas laba, dengan demikian IFRS berpengaruh terhadap kualitas laba. Qomariah (2013) yang meneliti pengaruh konvergensi IFRS pada manajemen laba melaporkan bahwa konvergensi IFRS menurunkan manajemen laba, dengan demikian konvergensi IFRS berpengaruh terhadap kualitas laba.

Tugas komite berhubungan dengan kualitas laporan keuangan, karena komite auditdiharapkan dapat membantu dewan komisaris dalam pelaksanaan tugas yaitu mengawasi proses pelaporan keuangan oleh manajemen. Peran komite audit sangat penting karena mempengaruhi kualitas laba perusahaan yang merupakan salah satu informasi penting yang tersedia untuk publik dan dapat digunakan investor untuk menilai perusahaan. Investor sebagai pihak luar perusahaan tidak dapat mengamati secara langsung kualitas sistem informasi perusahaan (Teoh dan Wong, 1993). Oleh karena itu, persepsi mengenai kinerja komite audit akan mempengaruhi penilaian investor terhadap kualitas laba perusahaan. Riset yang dilakukan oleh (Klien, 2001; DeFond dan Jiambalvo, 1991; McMulen, 1996; Beasly dan Salterio, 2001; McMullen dan Raghunandan, 1996), serta Suaryana (2005), berhasil membuktikan bahwa komite audit memberikan pengaruh positif terhadap kualitas laba.

Berdasarkan paparan dan hasil-hasil penelitian sebelumnya, maka dikemukakan hipotesis sebagai berikut:

H1 : Accounting Disclosure berpengaruh terhadap kualitas laba

H2 : Accounting Harmonization berpengaruh terhadap kualitas laba

H3 : Komite audit berpengaruh terhadap kualitas laba

\section{METODE}

Populasi dan sampel. Populasi dalam penelitian ini adalah seluruh perusahaan manufaktur yang terdaftar di Bursa Efek Indonesia selama periode 2009-2013. Sumber data dalam penelitian ini adalah data sekunder yaitu data dari laporan keuangan tahunan perusahaan manfaktur yang terdaftar di Bursa Efek Indonesia (BEI). Pemilihan sampel berdasarkan metode purposive sampling dengan tujuan mendapatkan sampel yang sesuai dengan kriteria yang ditentukan. Kriteria sampel yang digunakan dalam penelitian ini adalah semua perusahaan manufaktur yang terdaftar di Bursa Efek Indonesia selama periode 2009-2013 dan memenuhi persyaratan sebagai berikut: (1) Perusahaan yang 
terdaftar di Bursa Efek Indonesia selama periode 2009-2013; (2) Sampel termasuk dalam industri manufaktur berdasarkan pengklasifikasian Indonesian Capital Market Directory (ICMD) yang listing selama tahun 2009-2013; (3) Menerbitkan laporan tahunan pada tahun 2009-2013; (4) Laporan keuangan disajikan dalam bentuk rupiah; (5) Data yang tersedia lengkap, yaitu data yang diperlukan untuk mendekteksi pengungkapan kualitas laba; (6) Laporan tahunan perusahaan memiliki data-data yang berkaitan dengan variabel penelitian; (7) Perusahaan yang tidak melaporkan rugi selama periode penellitian; (8) Menyajikan laporan tata kelola perusahaan laporan komite audit dalam laporan tahunannya

Definisi Operasional dan Pengukuran Variable. Kualitas Laba. Kualitas laba merupakan jumlah yang dapat dikonsumsi dalam satu periode dengan menjaga kemampuan perusahaan pad awal dan akhir periode tetap sama (Schipper dan Vincent, 2003). Pada penelitian ini kualitas laba diukur menggunakan model jones yang dimodifikasi karena model ini dianggap lebih baik diantara model yang lain untuk mengukur manajemen laba (Dechow, 1995).

$$
\text { DAACit }=\beta 0+\beta 1 \text { ACHANGE }+\beta 2 \text { OWSHIP }+\beta 3 \text { AUDSIZE }+ \text { ei }
$$

Di mana: DAACit = discretionary accruals perusahaan i tahun $\mathrm{t}$; ACHANGE = persentase perubahan total asset tahun (it-1); OWSHIP = persentase kepemilikan saham oleh orang dalam; AUDSIZE = jumlah komite audit

Accounting Disclosure. Pengungkapan akuntansi adalah standar dan praktik pengungkapan dipengaruhi oleh sumber-sumber keuangan, sistem hukum, ikatan politik dan ekonomi, tingkat pembangunan ekonomi, tingkat pendidikan, budaya dan pengaruh lainnya. Pengungkapan akuntansi diuukur dengan menggunakan variabel dummy setiap perusahaan yang melaporkan laporan tahunan secara lengkap mendapatkan nilai satu, sedangkan perusahaan yang tidak melaporkan laporan tahunan secara lengkap akan mendapatkan nilai nol (Carolina dan Wardhani, 2011)

Accounting Harmonization. Harmonisasi merupakan proses untuk meningkatkan kompatibilitas (kesesuaian) praktik akuntansi dengan menentukan batasan-batasan seberapa besar praktik - praktik tersebut dapat beragam. Dalam mengukur harmonisasi akuntansi, penelitian ini menggunakan skala 1 sampai dengan 4 dengan gradiasi : (i) tidak ada standar setara lokal GAAP (1 poin), (ii) ada standar setara GAAP lokal tapi tidak sama sebagai IFRS, (iii) ada standar setara dalam GAAP lokal dan sama dengan IFRS dengan beberapa pengecualian, (iv) ada standar yang sama dalam GAAP lokal dan sama dengan IFRS untuk semua hal yang material (4 poin) (Carolina dan Wardhani, 2011).

Komite Audit. Komite audit merupakan pihak yang bertugas untuk membantu komisaris dalam rangka peningkatan kualitas laporan keuangan dan peningkatan kualitas audit internal dan eksternal. Keberadaan komite audit merupakan variabel dummy, bagi perusahaan yang memiliki komite audit akan mendapat nilai 1 (satu), sedangkan perusahaan yang tidak memiliki komite audit akan memiliki nilai 0 (nol) (Suaryana, 2005). 
Metode Analisis. Uji Asumsi Klasik. Uji asumsi klasik dilakukan untuk mengetahui hubungan antara variabel data. Uji asumsi klasik perlu dilakukan sebelum melakukan analisis regresi terhadap variabel tersebut.

Uji normalitas. Uji normalitas bertujuan untuk menguji apakah dalam model regresi, variabel pengganggu atau residuai memiliki distribusi normal. Karena model regresi yang baik adalah distribusi data normal atau mendekati normal (Ghozali, 2005). Cara menguji apakah residual berdistribusi normal atau tidak yaitu dengan menggunakan uji kolmogorov-smirnov. Uji Kolmogorov- Smirnov dilakukan dengan SPSS. Apabila nilai asympotic significant (two tailed) $>$ alpha $(\alpha=0,05)$ maka nilai residual memenuhi asumsi klasik atau berdistribusi normal.

Uji Multikolonieritas. Uji multikolonieritas bertujuan untuk menguji apakah dalam model regresi ditemukan adanya korelasi antara variabel bebas (Ghozali,2005). Model regresi yang baik seharusnya tidak terjadi korelasi antara variabel independen. Namun jika variabel independen saling berkorelasi, maka variabel-variabel ini dikatakan tidak orthogonal. Variabel orthogonal merupakan variabel independen yang nilai korelasinya sesama variabel adalah nol (Ghozali, 2005).

Cara untuk menguji ada tidaknya korelasi antar variabel independen adalah dengan melihat nilai tolerance dan variance inflaction factor (VIF). Kedua ukuran ini menunjukkan dari masing-masing variabel independen manakah yang dijelaskan oleh variabel independen lainnya. Nilai yang dipakai untuk menunjukkan adanya multikoloniearitas adalah nilai Tolerance 0.10 atau VIF 10. Selain menggunakan nilai tolerance dan VIF, cara yang dapat digunakan untuk mengetahui derajat multikolinearitas adalah dengan melihat hasil besaran korelasi antar variabel independen. Jika korelasinya massih dibawah 95\%, maka dapat dikatakan tidak terjadi multikoloneritas yang serius. Jika antar variabel independen terdapat korelasi yang cukup tinggi $(>0,90)$, maka terdapat indikasi bahwa terdapat mutikolonieritas.

Uji autokorelasi. Uji autokorelasi bertujuan untuk menguji apakah dalam model regresi linear ada korelasi antara kesalahan pengganggu pada periode $\mathrm{t}$ dengan kesalahan pengganggu pada periode t-1 (sebelumnya). Cara untuk mendeteksi ada atau tidaknya autokorelasi yaitu dengan uji Durbin Watson. Asumsi tidak terjadi autokorelasi terpenuhi jika nilai DW berada di antara nilai dU hingga (4-dU). Nilai bantu (dL dan dU untuk k = jumlah variabel bebas dan $n=$ jumlah sampel) diperoleh dari Tabel Durbin Watson.

Uji Heteroskedastisitas. Uji Heteroskedasitas bertujuan menguji apakah dalam model regresi terjadi ketidaksamaan variance dari residual dari suatu pengamatan ke pengamatan lain. Jika varian dari residual satu pengamatan ke pengamatan lain tetap maka disebut homoskedastisitas sedangkan regresi yang baik adalah tidak ada heteroskedastisitas. Untuk mendeteksi heteroskedasitas pada penelitian ini maka digunakan metode Park Glejser. Dengan menggunakan metode ini gejala heteroskedasitas akan ditunjukkan oleh koefisien regresi dari masing-masing variabel independen terhadap nilai absolut residunya. Jika nilai signifikansinya $>$ nilai alphanya $(\alpha=0,05)$, maka dapat dipastikan model ini tidak mengandung unsur heteroskedastisitas (Gujarati, 2000).

Regresi Linier Berganda. Regresi linier berganda digunakan untuk menguji pengaruh variabel-variabel independen terhadap dependen dengan rumusan sebagai berikut: 


$$
\operatorname{KLB}(\mathrm{DA})=\alpha+\beta 1 \mathrm{AD}+\beta 2 \mathrm{AH}+\beta 3 \mathrm{KA}+\mathrm{e}
$$

Di mana: $\mathrm{KLB}(\mathrm{DA})=$ discretionary accrual; $\alpha=$ konstanta; $\beta=$ koefisien regresi; $\mathrm{AD}$

$=$ accounting disclosure; $\mathrm{AH}=$ accounting harmonization; $\mathrm{KA}=$ komite audit; $\mathrm{e}=$ standar error

Pengujian Hipótesis. Uji F. Uji statistik F pada dasarnya menunjukkan apakah semua variabel independen yang mempunyai pengaruh secara bersama-sama terhadap variabel dependen (Ghozali, 2005). Pengujian dilakukan dengan cara mengukur nilai probabilitas signifikasi. Jika nilai probabilitas signifikasi 0.05 maka hipotesis tidak dapat ditolak. Ini berarti secara bersama-sama variabel independen mempunyai pengaruh secara signifikan terhadap variabel dependen. Namun sebaliknya jika nilai probabilitasnya 0.05 maka hipotesis ditolak. Ini berarti secara bersama-sama variabel independen tidak mempunyai pengaruh yang signifikan terhadap variabel dependen.

Uji t. Uji statistik t merupakan uji statistik yang bertujuan untuk melihat seberapa jauh pengaruh satu variabel independen terhadap variabel dependen (Ghozali,2005). Jika hasil pengujian menghasilkan nilai t-hitung $>\mathrm{t}$-tabel atau t-hitung $<\mathrm{t}$-tabel maka variabel independen secara individu memiliki pengaruh terhadap variabel dependen.

\section{HASIL DAN PEMBAHASAN}

\section{Statistik Deskriptif.}

Tabel 1. Sampel yang digunakan dalam penelitian ini sebagai berikut:

\begin{tabular}{lc}
\hline \multicolumn{1}{c}{ Seleksi sampel Jumlah } \\
\hline $\begin{array}{l}\text { Perusahaan manufaktur yang terdaftar di BEI } \\
\text { periode }\end{array}$ & 156 \\
Perusahaan yang delesting dari BEI periode & $(19)$ \\
$\begin{array}{l}\text { Perusahaan manufaktur yang menerbitkan } \\
\text { laporan keuangan selama periode 2009-2013 }\end{array}$ & \\
tidak secara rutin & 13 \\
Perusahaan manufaktur yan melaporan rugi & \\
selama periode 2009-2013 & 48 \\
Jumlah perusahaan terpilih & 200 \\
\hline
\end{tabular}

Uji Asumsi Klasik. Uji Normalitas. Berdasarkan hasil analisis data dengan bantuan software SPSS for Windows. Variabel dinyatakan menyebar dengan normal jika hasil uji kolmogorov smirnov standarized residual menunjukkan jika nilai assympatic significant (2-tailed) > alpha $(0,05)$. Pada tabel, dapat diketahui bahwa nilai Kolmogorov Smirnov test sebesar 1,182, sedangkan nilai asymp. sig. (2-tailed) untuk unstandardized variable sebesar 0,113 lebih besar dari nilai a yaitu 0,05, sehingga dapat disimpulkan bahwa data yang digunakan berdistribusi normal. 
Tabel 2. One-Sample Kolmogorov-Smirnov Test

\begin{tabular}{llrr}
\hline & & \multicolumn{1}{l}{ JV7 } & \multicolumn{1}{l}{ JV13 } \\
\hline $\mathrm{N}$ & & 48 & 48 \\
Normal Parameters $^{\mathrm{a}}$ & Mean & 20.54 & 20.07 \\
& Std. Deviation & 2.478 & 2.171 \\
Most Extreme & Absolute & .167 & .128 \\
Differences & Positive & .140 & .113 \\
& Negative & -.167 & -.128 \\
Kolmogorov-Smirnov Z & & 1.182 & .941 \\
Asymp. Sig. (2-tailed) & & .113 & .338 \\
\hline
\end{tabular}

a. Test distribution is Normal.

Uji Multikolonieritas. Hasil uji multikolonierits menunjukkan bahwa variabel accounting disclosure, harmonisasi akuntansi dan komite audit memiliki nilai tolerance 0,1 dan nilai VIF dibawah 10 yang berarti variabel -variabel tesebut tidak terjadi multikolineritas.

Tabel 3. Hasil uji Multikolineritas

\begin{tabular}{cccc}
\hline Variabel & \multicolumn{2}{c}{ Collinearity Statistics } & Kesimpulan \\
\cline { 2 - 4 } bebas & Tolerance & VIF & \\
\hline constant & & & \\
AD & 0,873 & 1,089 & Tidak ada multikolineritas \\
AH & 0,866 & 1,569 & Tidak ada multikolineritas \\
KA & 0,930 & 1,733 & Tidak ada multikolineritas \\
\hline
\end{tabular}

Uji Autokorelasi. Berdasarkan hasil uji Durbin-Watson dengan bantuan software SPSS for Windows yang telah dilakukan, diperoleh nilai Durbin-Watson sebesar 1,809 . Nilai tersebut dibandingkan dengan nilai Durbin Watson tabel untuk $\mathrm{n}=48$ dan $\mathrm{k}=4$ dengan ( $\alpha$ ) 0,05 atau $5 \%$, maka nilai $d_{U}=1,72$ dan $d_{L}=1,41$. Jadi nilai uji Durbin Watson berada di antara $\mathrm{d}_{\mathrm{U}}$ dan 4 - $\mathrm{d}_{\mathrm{U}}$. Hal ini merupakan bukti tidak adanya autokorelasi positif maupun negatif

Uji Heterokedesitas. Probabilitas variabel accounting disclosure. Harmonisasi akuntansi, komite audit secara statistik signifikansinya di atas 5\%. Jadi dapt disimpulkan bahwa model regresi tidak terdapat heterokedesitas.

Tabel 4. Hasil uji Heterokedesitas

\begin{tabular}{cccc}
\hline Variabel terikat & Variabel bebas & Sig.t & Keterangan \\
\hline ABS & AD & 0,233 & Bebas heterokedisitas \\
& AH & 0,145 & Bebas heterokedisitas \\
& KA & 0.341 & Bebas heterokedisitas
\end{tabular}

Uji Hipotesis. Berdasarkan hasil olah data didapat hasil uji regresi linier berganda sebagai berikut: 
Tabel 5. Hasil uji regresi berganda

\begin{tabular}{|c|c|c|c|c|c|c|}
\hline \multirow[b]{2}{*}{ Mod } & & \multicolumn{2}{|c|}{ Unstandardized Coefficients } & $\begin{array}{l}\text { Standardized } \\
\text { Coefficients }\end{array}$ & \multirow[b]{2}{*}{$\mathrm{t}$} & \multirow[b]{2}{*}{ Sig. } \\
\hline & & B & Std. Error & Beta & & \\
\hline \multirow[t]{4}{*}{1} & (Constant) & 4,852 & 1,595 & & 2,282 & 0,243 \\
\hline & $\mathrm{AD}$ & 0,264 & 0,097 & 0,437 & 4,008 & 0,000 \\
\hline & $\mathrm{AH}$ & 0,234 & 0,143 & 0,333 & 2,901 & 0,001 \\
\hline & KA & 0,356 & 0,122 & 0,307 & 2,191 & 0,038 \\
\hline
\end{tabular}

Sehingga diperoleh persamaan regresi sebagai berikut:

$\mathrm{KLB}(\mathrm{DA})=4,852+0,264 \mathrm{AD}+0,234 \mathrm{AH}+0,356 \mathrm{KA}+\mathrm{e}$

Hasil uji f.Berikut hasil kesimpulanm yang diambil dari uji f:

Tabel 6. Hasil uji $\mathrm{f}$

\begin{tabular}{|c|c|c|c|c|c|c|}
\hline Model & & Sum of Squares & $\mathrm{df}$ & Mean Square & $\mathrm{F}$ & Sig. \\
\hline \multirow[t]{3}{*}{1} & Regression & 135,524 & 3 & 45,175 & 29,843 & $.000^{\mathrm{a}}$ \\
\hline & Residual & 50,058 & 26 & 1.925 & & \\
\hline & Total & 185,581 & 29 & & & \\
\hline
\end{tabular}

Berdasarkan hasil uji f, dilihat nilai probabilitas 29.843 dengan signifikansi 0,000. Hasil df juga menunjukkan nilai 26 dan 29. Nilai f hitung lebih besar dari f tabel yaitu 29,843 > 2,463 sehingga disimpulkan bahwa secara simultan variabel accounting disclosure, harmonisasi akuntansi dan komite audit berpengaruh terhadap kualitas laba.

Hasil uji t. Uji t digunakan untuk menguji secara parsial, statistik signifikansi variabel accounting disclosure, harmonisasi akuntansi, komite audit dan kualitas laba. Berikut hasil pengujian uji $\mathrm{t}$

Tabel 7. Hasil uji t

\begin{tabular}{|c|c|c|c|c|c|c|}
\hline \multirow{2}{*}{\multicolumn{2}{|c|}{ Model }} & \multicolumn{2}{|c|}{ Unstandardized Coefficients } & $\begin{array}{l}\text { Standardized } \\
\text { Coefficients }\end{array}$ & \multirow{2}{*}{ t } & \multirow[b]{2}{*}{ Sig. } \\
\hline & & \multirow{2}{*}{$\begin{array}{l}\text { B } \\
4,852\end{array}$} & \multirow{2}{*}{$\begin{array}{r}\text { Std. Error } \\
1,595\end{array}$} & Beta & & \\
\hline \multirow[t]{4}{*}{1} & Iodel & & & & 2,282 & 0,243 \\
\hline & $\mathrm{AD}$ & 0.723 & 0.834 & 0,007 & 1,121 & \multirow{2}{*}{$\begin{array}{l}0,346 \\
0,000\end{array}$} \\
\hline & \multirow{2}{*}{$\begin{array}{l}\mathrm{AH} \\
\mathrm{KA}\end{array}$} & 0,264 & 0,097 & \multirow{2}{*}{$\begin{array}{l}0,437 \\
0,307\end{array}$} & 4,008 & \\
\hline & & 0,356 & 0,122 & & 2,191 & $\begin{array}{l}0,000 \\
0,038\end{array}$ \\
\hline
\end{tabular}

Accounting Disclosure berpengaruh terhadap kualitas laba. Dari hasil perhitungan didapat bahwa variabel accounting disclosure memiliki t hitung 1,121 < t tabel 1,960 dengan signifikasni 0,346 probabilitas di atas 0,05 sehingga disimpulkan bahwa tidak ada pengaruh antara variabel accounting disclosure terhadap kualitas laba. Hasil penelitian ini menunjukkan bahwa kelengkapan pengungkapan akuntansi yang dilaporkan oleh suatu 
perusahaan tidak memiliki pengaruh terhadap kualitas laba. Hasil ini tidak mendukung penelitian yang dilakukan Carolin dan Wardhani (2011).

Pengungkapan akuntansi (accounting disclosure) adalah standar dan praktik pengungkapan dipengaruhi oleh sumber-sumber keuangan, sistem hukum, ikatan politik dan ekonomi, tingkat pembangunan ekonomi, tingkat pendidikan, budaya dan pengaruh lainnya. Fenomena di Indonesia menunjukkan bahwa tingkat pengungkapan akuntansi (accounting disclosure ) yang dibuat oleh manajemen hanya memberikan manfaat pada ruang lingkup mengatasi asimetri informasi antara pemegang saham dan manajemen tetapi tidak memberikan pengaruh signifikan terhadap kualitas laba.

Accounting Harmonization terhadap kualitas laba. Dari hasil perhitungan didapat bahwa variabel accounting harmonization memiliki t hitung 4,008 < t tabel 1,960 dengan signifikasni 0,000 probabilitas di bawah 0,05 sehingga disimpulkan bahwa accounting harmonization berpengaruh terhadap kualitas laba. Hasil penelitian ini konsisten dengan penelitian Carolina dan Wardhani (2011) yang menunjukkan bahwa harmonisasi akuntansi berpengaruh positif terhadap kualitas laba. Penerapan IFRS ini diharapkan dapat memberi banyak manfaat salah satunya adalah meningkatkan kualitas pelaporan keuangan bagi para pemegang kepentingan. Namun manfaat ini juga dipengaruhi oleh lingkungan dimana IFRS tersebut diterapkan, dalam hal ini perlindungan yang diberikan bagi investor di suatu negara.

Dengan adanya penerapan harmonisasi akuntansi mengakibatkan adanya standar yang diterima secara internasional yang sama, transparansi dan komparabilitas laporan keuangan dapat direalisasikan, perlindungan investor juga akan meningkat karena penggunaan IFRS berorientasi kepada kepentingan investor. Secara garis besar disimpulkan adanya penggunaan standar akuntansi yang tercakup dalam harmonisasi akuntansi akan memperkuat pengaruh tingkat pengungkapan kualitas laba.

Komite audit terhadap kualitas laba. Dari hasil perhitungan didapat bahwa variabel komite audit memiliki t hitung 2,191 < t tabel 1,960 dengan signifikasni 0,038 probabilitas di bawah 0,05 sehingga disimpulkan bahwa komite audit berpengaruh terhadap kualitas laba. Hasil penelitian menunjukkan bahwa variabel komite audit berpengaruh postif terhadap kualitas laba yang mengindikasikan bahwa keberadaan komite audit dalam suatu perusahaan akan meningkatkan kualitas laba yang akan dihasilkan perusahaan tersebut. Penelitian ini mendukung penelitian sebelumnya Suaryana (2003), Wijayanti (2013) yang mengungkapkan bahwa kualitas laba perusahaan yang membentuk komite audit lebih berkualitas daripada perusahaan yang tidak membentuk komite audit. Komite audit yang berkeahliann di bidang akuntansi dan keuangan mampu mendorong peningkatan kualitas laba. Adanya keberadaan komite audit independen serta memiliki keahlian dalam bidang akuntansi dan keuangan adalah sinyal persepsi kredibilitas dan kualitas laba perusahaan yang lebih baik. Laba yang kredibel dan berkualitas baik akan direspons lebih kuat oleh pihak-pihak yang berkepentingan.

\section{PENUTUP}

Simpulan. Dari hasil riset ini diperoleh kesimpulan bahwa: Pertama. Tidak terdapat pengaruh antara variabel accounting disclosure terhadap kualitas laba. Hasil ini tidak 
mendukung penelitian yang dilakukan Carolin dan Wardhani (2011). Fenomena di Indonesia menunjukkan bahwa tingkat pengungkapan akuntansi (accounting disclosure ) yang dibuat oleh manajemen hanya memberikan manfaat pada ruang lingkup mengatasi asimetri informasi antara pemegang saham dan manajemen tetapi tidak memberikan pengaruh signifikan terhadap kualitas laba. Kedua. Accounting Harmonization berpengaruh terhadap kualitas laba. Hasil penelitian ini konsisten dengan penelitian Carolina dan Wardhani (2011) yang menunjukkan bahwa harmonisasi akuntansi berpengaruh positif terhadap kualitas laba. Adanya penggunaan standar akuntansi yang tercakup dalam harmonisasi akuntansi akan memperkuat pengaruh tingkat pengungkapan kualitas laba. Ketiga. Komite audit berpengaruh postif terhadap kualitas laba. Penelitian ini mendukung penelitian sebelumnya Suaryana (2003), Wijayanti (2013) yang mengungkapkan bahwa kualitas laba perusahaan yang membentuk komite audit lebih berkualitas daripada perusahaan yang tidak membentuk komite audit. Komite audit yang berkeahliann di bidang akuntansi dan keuangan mampu mendorong peningkatan kualitas laba.

Saran. Adapun saran untuk penelitian selanjutnya, agar dapat mempertimbangkan hal hal sebagai berikut: (1) Sebaiknya menambah jumlah dan kuota sampel dengan tidak menggunakan sampel perusahan manufaktur saja guna kelengkapan dan kompleksitas hasil penelitian; (2) Penelitian selanjutnya dapat menambah literatur variabel lain yang mempunyai pengaruh terhadap kualitas laba; (3) Penelitian sebaiknya dapat menambah periode penelitian,dengan menambah periode penelitian yang lebih valid dan up to date/ terkini.

\section{DAFTAR RUJUKAN}

Adhariani (2005) ”Tingkat Keluasan Pengungkapan Sukarela Dalam Laporan Tahunan dan Hubungannya Dengan Current Earnings Response Coefficient (ERC)”. Jurnal Akuntansi dan Keuangan Indonesia. 2 (1): 24-57

Ali, A. Dan P. Zarowin, (1992) "Permanent vs. Transitory Components of Annual Earnings and Estimation Error in Earning Response Coefficients". Journal of Accounting and Economics, 15, 249-64

Basu, Sudipto (1977) "The conservatism principle and the asymmetric timeliness of earnings”. Journal of accounting and economics. 24, pp. 3-37

Bradbury, M. E., Mak, Y. T. dan Tan, S. M. (20040 "Board Characteristics, Audit Committee Characteristics and Abnormal Accruals”. Working Paper. Unitec New Zealand dan National University of Singapore.

Beaver, W.H. Clark, R, W.F. Wright. (1979) "The Association between unsystemic security returns and the magnitude of earning forecast error". Journal of Accounting Research. 17: 316-340

Beasly, M. S. dan Salterio, S. E. (2001) "Relation Between Board Characteristics and Voluntary Improvements in Audit Committee Composition and Experince”. Contemporary Accounting Research, 18 (4): 539-570.

Carolina, Alfon Inggrid, Ratna Wardhani. (2011) "The effect of accounting disclosure, concentrated ownership and accounting harmonization to earning quality". Makalah Simposium Nasional Akuntansi XIV. Aceh 
Cho, J.Y and K. Jung. (1991) 'Earnings Response Coefficient: A Sythesis of Theory and Empirical Evidence’. Journal of Accounting Literature. 10: 85-116.

Fitriani (2001) Signifikasi Perbedaan Tingkat Kelengkapan Pengungkapan Wajib Dan Sukarela Pada Laporan Keuangan Perusahaan Publik Yang Terdaftar Di Bursa Efek Jakarta. Makalah Simposium Nasional Akuntansi IV, Bandung: Universitas Padjajaran dan Ikatan Akuntan Indonesia pp.133-154.

Hair, Anderson, Tatham, Black (1995) Multivariate Data Analysis. $5^{\text {th }}$ ed. Pearson Education

Jensen-Meckling (1976) "The Agency Theory Of The Firm: Managerial Behavior, Agency Cost And Ownership Structure” Journal of Financial Economics, 3: 305360

Jerry W, Lin, June F, Li, Joon S. Yang (2006) "The effect of audit committee performance on earnings quality", Managerial Auditing Journal, 21 (9): 921 - 933

Lev (1989) "On usefulness of earnings: Lesson ans directions from two decades of empirical research”. Journal of Accounting Research 27 (supplement) pp. 153-192

Lipe, R.C., (1990) "The Relations Between Stock Return, Accounting Earnings and Alternative Information”, Accounting Review (Januari): 49-71.

Mayangsari, Sekar. (2009) The influence of International Accounting Standard on Earning Quality. Simposium Nasional Akuntansi XII

McMullen, D. A. dan Raghunandan, K. (1996) "Enhancing Audit Committee Effectiveness”. Journal of Accounting. Agustus 1996

Nugrahanti, Yeterina Widi (2006) “Hubungan Antara Luas Ungkapan Sukarela Dalam Laporan Tahunan Dengan Earnings Response Coefficient Dan Volume Perdagangan Pada Saat Pengumuman Laba”. Jurnal Ekonomi dan Bisnis, XII (2): 152-171.

Schwartz, K., dan Soo, B., (1996) "Evidence of Regulatory Non-Compliance with SEC Disclosure Rules on Auditor Changes”. The Accounting Review 4th Ed. October.

Syafrudin, M. (2004) Pengaruh Ketidaktepatwaktuan Penyampaian Laporan Keuangan pada Earnings Response Coefficient: Studi di BEJ. Simposium Nasional Akuntansi VII: 754-765.

Suaryana, Agung. (2005) Pengaruh komite audit terhadap kualitas laba. Simposium Nasional Akuntansi VII. Solo

Widiastuti, Harjanti, (2002) Pengaruh Luas Ungkapan Sukarela Terhadap Reaksi Investor. Simposium Nasional Akuntansi VI: 1314-1326. 